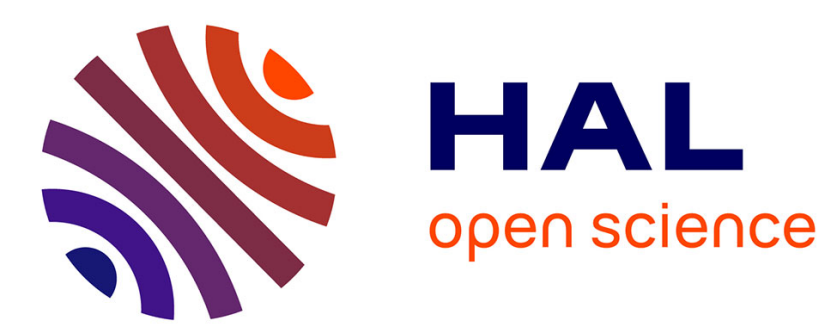

\title{
Landscape commons, following wind power fault lines: The case of Seine-et-Marne (France)
}

\author{
Alain Nadaï, Olivier Labussiere
}

\section{To cite this version:}

Alain Nadaï, Olivier Labussiere. Landscape commons, following wind power fault lines: The case of Seine-et-Marne (France). Energy Policy, 2017, 109, pp.807-816. 10.1016/j.enpol.2017.06.049 . halshs-01675634

\section{HAL Id: halshs-01675634 \\ https://shs.hal.science/halshs-01675634}

Submitted on 20 Dec 2018

HAL is a multi-disciplinary open access archive for the deposit and dissemination of scientific research documents, whether they are published or not. The documents may come from teaching and research institutions in France or abroad, or from public or private research centers.
L'archive ouverte pluridisciplinaire HAL, est destinée au dépôt et à la diffusion de documents scientifiques de niveau recherche, publiés ou non, émanant des établissements d'enseignement et de recherche français ou étrangers, des laboratoires publics ou privés. 


\section{Landscape commons, following wind power fault lines}

The case of Seine-et-Marne (France)

AUHTORS DRAFT, PLEASE REFER TO THE PUBLISHED VERSION FOR ANY CITATION

Contribution to a special issue on the COllaborative “MAKING” OF ENERgy LANDSCAPES

Alain Nadaï ${ }^{1}$ - CIRED - Jardin Tropical, 45 bis, Avenue de la Belle Gabrielle, 94736 Nogent -sur-Marne Cedex, France - Tel. 33 (0) 143947387 - nadai@centre-cired.fr

Olivier Labussière - PACTE, Institut de Géographie Alpine - 14bis, avenue Marie Reynoard, 38100 Grenoble, olivier.labussiere@umrpacte.fr

\section{ABSTRACT}

Our contribution aims at adding to the understanding of opposition to wind power. We follow the progressive emergence and structuring of a so-called "opponent" network to a highly conflictual wind power project (Seine-et-Marne, Parisian basin, France), paying particular attention to the shared landscape resources engaged in the development of this project.

The paper draws on various strands of literature interested in landscape as a socio-material assemblage, a commons as a collective management of shared resources, and issues such as a political articulation of matters of public concern.

Our case study suggests that local opposition to wind power is symptomatic of the shortcomings of French institutions' treatment of the shared resources engaged in the development of wind power projects. So-called "opponents" to wind power are not opponents per se. Rather, opposition arises from the tension exerted by (French, privately developed) wind power with respect to shared (relational, landscape) resources. Thus opposition and landscape issues in relation to wind power can just as well be regarded as demands to recognize the necessary collective underpinnings of wind power projects.

\section{HIGHLIGHTS}

- The paper contributes to the understanding of opposition to wind power.

- "Opponents" to wind power are not opponents per se.

- Opposition arises from the tension exerted by wind power with respect to shared resources.

\footnotetext{
${ }^{1}$ Corresponding author : CIRED - Jardin Tropical, 45 bis, Avenue de la Belle Gabrielle, 94736 Nogent -sur-Marne Cedex, France - Tel. 33 (0) 1 43947387 - nadai@centre-cired.fr
} 
- French wind power institutions fall short of acknowledging the shared (relational, landscape) resources engaged in the development of wind power projects.

- Opposition to wind power can just as well be regarded as the demand to recognize the necessary collective underpinnings of wind power projects

\section{KEYWORDS}

Wind power - opposition - landscape - commons - resources - France

\section{WORD COUNT}

8226 


\section{INTRODUCTION}

Landscape issues in wind power development, planning and projects have been the subject of an extended literature. Yet the different, multiple existences of landscape in wind power processes, whether visual, a collective practice or an institutional or legal entity, have not been thoroughly analyzed. In particular, the ways in which landscape is rendered present in wind power processes through its shared/collective dimension, which may come to be challenged and contested in these processes, demands a better understanding.

This article explores the question on the basis of a contested wind power project in a village in Seine-et-Marne (Parisian Basin, France). The project under consideration was the first to be developed in the Île-de-France. Its process started in 2005. The project received a favorable administrative decision in 2009 and was cleared after appeal in 2013. It was supposed to go into service in 2014. The project aroused violent oppositions (breaking of family ties, breakdown of community life, physical violence, property damage) and shattered the articulation between the private and the public spheres that underlaid village life and the local political practice.

Our analysis follows the emergence, the progressive constitution and the structuring of oppositional trajectories, starting with individuals who did not have an a priori position vis-àvis wind power ${ }^{2}$. At the heart of this wind power drama, we explore the role of the centralized French administrative tradition of landscape protection, for which we coin the expression "state landscape", specifically in its difficulties to acknowledge locally shared landscape (commons) and support the emergence of a shared dimension for this wind power project.

We thus attempt to clarify the different roles of landscape in such a conflicting situation and their relations to the potentially collective dimension of this project. We do so by drawing on ideas of "commons" (Ostrom, 2013; Coriat, 2013) and of "public" and "issues" as treated in the pragmatic tradition (Marres, 2007). Such a perspective emphasizes the collective dimension/construction of wind power development and, its possibility and conditions for emergence. It evidently departs from the usual "nimby" analyses in that it does not presuppose that opposition to wind power is geared to individual interest or precedes project development. Instead, it leaves open the possibility that opponents could have followed another path and that their trajectory or demands conveyed an alternative wind power becoming.

We proceed in three steps. The first part of the paper presents our approach and elements of context. The second part analyzes the case of the village of Ventville ${ }^{3}$ (Seine-et-Marne, France), highlighting the difficult way in which the articulation between the public and private dimensions of French power policy is played out. The third section turns to a discussion of the relationship between landscape, commons and wind power policy.

\section{LANDSCAPE, COMMONS: A WIND POWER PROJECT AND ITS PUBLIC}

\subsection{OPPOSITION TO WIND POWER}

\footnotetext{
${ }^{2}$ A slightly different analysis of this case study has been published in French: Nadaï \& Labussière, 2014

${ }^{3}$ A pseudonym used for the sake of confidentiality.
} 
Landscape issues in relation to onshore wind power have been important since the take-off of wind power in countries such as France in the early $2000 \mathrm{~s}^{4}$. Issues pertaining to wind power have also developed in other European countries such as Denmark and Germany, however famous they may be for their successful "civic model based on local ownership of wind farms (Bolinger, 2007; Meyer, 2007; Nielsen, 2002). A striking feature in social science literature about wind power development is the uneven consideration of landscape issues. Some analysts have attempted to relate landscape issues to visual impact through quantification (Bishop 2007; Möller, 2010). Others have discussed landscape issues in relation to the extent of public consultation and deliberation in planning (Aitken et al., 2008; Ellis et al., 2009; Wolsink, 2009; Toke et al., 2008; Zografos \& Martínez-Alier, 2009; Gee, 2010), or by pointing to the ways in which landscape was represented in planning processes (Cowell, 2010; Nadaï, 2012; Nadaï \& Labussière 2009 \& 2010; Labussière \& Nadaï, 2014; Jolivet \& Heiskanen 2010). In this paper, we explore a slightly different route: we build on insights from political ecology, pragmatist sociology and institutional theory in order to foreground the role of landscape as a shared resource in the development of wind power and in underpinning local opposition.

\subsection{LANDSCAPE AND THE ONTOLOGICAL TROUBLE}

Political ecology scholars have recently developed a strand of research interested in conflicts triggered by unconventional energy developments, notably fracking (Pearson, 2016; Willow \& Willie, 2014; Willow, 2014; Willow et al. 2014). They explore how these developments impact on the ways in which landscape is experienced by local inhabitants. They rely on the idea of landscape that is familiar to landscape studies, which conceive of landscape as a relationship and a process (Hirsch, 1995; Mitchell, 1994), and encompasses the various ways in which people understand and engage with the material world around them. So defined, landscape is a contested thing (Bender, 1998). Explorations of the effect of fracking processes show that tensions pertain to various dimensions such as the anxiety induced by physical harm (or its threat, either tangible or not, real or imagined) or the change in the usual human relation to the environment. Landscape thus results in being contested at the level of experience and at the symbolic level, notably because of conflicts between ways of envisioning the ideal relation between human beings and the environment (the environment as a place for human-environment relation) and the priorities that are foregrounded by public policies (environment as an opportunity for economic development). Conflict stems from the destabilisation of the intricate relations among different dimensions of landscape and results in what has been called "ontological displacement", in the sense of an alteration of social relations and sense of belonging: "[...] mining transforms landscapes, introduces new hazards, and alters social relationships, some feel alienated from places that previously grounded their sense of belonging" (Pearson, 2016:50).

\subsection{OPPOSITION AS A PUBLIC-IN-THE-MAKING}

Ontological displacement in the sense of a change in identity - from villagers to "opponents" to wind power - associated with a destabilisation in the sense of belonging to a place (the village and the village life) is the core to our case study. The idea echoes that of ontological trouble, which is the core of the pragmatist approach to democracy in political philosophy (Dewey, 2003) and its most recent reinterpretation in the analysis of material participation

\footnotetext{
${ }^{4}$ For France, see, for instance, Nadaï, 2007a. For the United Kingdom,, Cowell, 2010, Toke et al. 2008.
} 
(Marres, 2012). To put it in a nutshell, the rise and centrality of technologies in modern society have made political participation necessary but increasingly, if not essentially, problematic because of the many interferences generated by these technologies (Latour, 1991; Callon, Lascoumes \& Barthe, 2001; Pestre, 2013). The ensuing challenge for the actors who are intimately affected by technological development (called a "public") is to make themselves relevant - for instance, by becoming capable of accessing and acting in the spheres where decisions are made in order to influence the course of this development. This issue has been assimilated to ontological trouble because this "public" is concerned but not necessarily relevant, and because of ontological redefinitions, and associated redistributions of political capacities, are at work in these processes (Marres, 2012).

Pragmatist sociology thus starts by paying attention to the consequences of activities on actors and entities. It directs specific attention to the ways in which this "public" attempts (and in certain cases succeeds) collectively to articulate the consequences its experiences and turn them into shared concerns so as to have them be acknowledged in the policy processes. As suggested by Noortje Marres (2007), a good starting point in analyzing a process of politicization is the idea of "issue" or "matter of concern". The term "issue" points to the indistinct status of a concern when ongoing practices, categories or codes (economic, political, scientific) fall short of taking responsibility for it. As the name suggests, the future of an issue is to find a way out, a way to be categorized, stabilized and governed. The process by which an "issue" emerges is a political one; it is the moment in which a "public" comes into being (Dewey, 2003). The public is thus inseparable from the issue. It is a collective of people concerned with this issue and attempting to articulate it as a "problem" in order to make it public. Noortje Marres insists that the construction of a "problem" requires a collective and collective work.

\subsection{LANDSCAPE AS A COMMON AND A TERRAIN FOR CONTESTATION}

Landscape is a terrain in which the setting of turbines and the types of appropriation they call for (rents, contracts, visual presence, works) become perceptible if not tangible in many ways. It is thus a terrain around which issues and publics in relation to wind power development often arise. In order to understand the politicization of wind power at the interface between the (privately developed) project and landscape concerns, it is essential to account for the diverse modes of appropriation at work in the landscape.

We owe to Elinor Ostrom (2013) the proposal to replace the Public ${ }^{5}$ (state) vs private (market) dichotomy in property rights analysis with careful attention to the variety of collective forms of organization around (and the regulation of) commonly pooled resources. As Ostrom (2013) and others (Coriat, 2013) have proposed, the term "commons" indicates non-state forms of collective appropriation, more informal yet possibly underpinned by elaborate forms of management. While Ostrom has advanced a rational model of collective organization based on a neat distinction of types of rights, others have expanded her proposal by considering ordinary practices as enactments of rights, allowing for a less formalized yet relevant discussion of new forms of commons (Coriat, 2015; Ostrom and Basurto, 2013; Bellivier et al. 2015). In our case study, the forms of landscape appropriation are partly informal and the straightforward implementation of Olson's framework therefore seems impractical. While retaining Ostrom's proposal, our empirical configuration thus

\footnotetext{
${ }^{5}$ We here capitalize "Public" to indicate the state/market or Public/private dichotomy, which Ostrom's seminal work proposes to overcome, and to distinguish this acception of the term from the pragmatist notion of "public" as a collective of concerned actors.
} 
demands another way of understanding the emergence and the trajectory of existing landscape commons of existing landscape commons.

In France, landscape is involved in several ways and at several stages in the development of wind power projects: either as a material realm, an institutional or a cultural category (Nadaï \& Labussière O., 2009 \& 2010). Upstream project development, at the stage of spatial planning: the devising of planning schemes or of Wind Power Development Zones (WPDZ) mixes formal processes and landscape representations - such as standard sieve mapping exercises based on the zoning/mapping of protected fauna or flora, and of registered or classified heritage items, etc. - with more open and informal ones, such as public meetings or consultations with the public about the uses of the landscape and the local population's attachment to it. At the level of project development, this same mix of codified/less codified elements feeds the devising of impact studies and administrative notification, all of which then serve as a basis for a public inquiry (during citizens can consult these documents and initiate petitions). The final administrative decision about the project is made by the local representative of the French State, the départmental Prefect, on the basis of all these components. The public inquiry, which thus takes place between the administrative notification and the Prefect's decision, is the occasion for the petitioners to express their attachment to certain elements or dimensions of the landscape, to invoke their practices with respect to the landscape, and possibly to point out the lack of coverage of important and/or protected elements of landscape, flora or fauna in the impact studies. Finally, appeals to the administrative court (against the Prefect's decision) are usual. This legal process narrows down the issue to the so-called "enforceable" landscape, mainly, registered or classified heritage elements or landscapes, since only these possess a judicial value.

Figure 1. [Please insert here]

As a way of clarifying the approaches to landscape in these processes, we have coined the expression "state landscape" (Nadaï, Labussière O., 2011, 2015). In France, the state's approach to landscape is rooted in the administrative approach to monuments and their surroundings, which dates from the early twentieth century. It laid the foundation for a form of institutional objectification of landscape. The primacy of the visual and the geometry of space (co-visibilities, plan delimitation through zoning) are usual state means of making landscape part of the "public good" and legitimating action. This "state landscape" translates into a multitude of (state-declared) protected areas, which become a structural component of the territory. They reflect only very partially the actual, on-site individual or collective forms of appropriation of the landscape. Arguably, this administrative tradition of centralized protection can be regarded as a form of commons: it is considered part of the national heritage. and its access and enjoyment must be guaranteed to all by the State.

The Ventville case study, however, displays two other types of "landscape commons". A first level of collective appropriation corresponds to elements of landscape, often under open access, welcoming bundles of uses and practices that overlap without any of them limiting or diminishing the others. As we will see in the case study, the "plain" is an agricultural area, free of infrastructure, valued by farmers in their work, by hunters for sport and by villagers for their Sunday walk. Our interviews do not allow an analysis of the informal modes of coordination amongst these groups of users of the plain, if any (nor was it their primary purpose). We thus choose to consider the landscape as a mere shared resource, that is to say, shared through relatively informal uses. A second level of collective appropriation 
consists in the combination of a landscape resource with an organizational form or a form of organized collective action, which acknowledges the shared uses of this landscape and aims at regulating them. An example of this is a farmers' land consolidation association (periodically) making possible a fair and equitable process of land re-organization in the plain.

\subsection{FOLLOWING THE LANDSCAPE, FOLLOWING OPPONENTS}

Following landscape commons allows us to approach the politicization of wind power issues at the interface between the privately developed wind power project and these (shared) commons. Politicization, in our case study, relates to the lack of legal or institutional embedding of the collective resources that are mobilized, but not acknowledged, by the development of the project. It occurs at the level of the local politics and of the coarticulation of the private and public spheres on which the village life and politics relies. The lack of clear institutional or legal articulation between the state landscape, the shared (landscape) local resources and the (privately developed) wind power project results in challenging the purported public interest in wind power (as a state supported solution to climate change). It turns the project into an issue and ends up challenging the villagers' sense of village life and of belonging to the place.

In the village of Ventville, where the project is located, the local political practice was traditionally anchored in a subtle articulation between the private sphere and the public village life: the voter is a neighbor, the farmer is a colleague and a Sunday stroller, the wind power opponent is a relative or a friend. As the project jeopardizes certain landscape commons, it triggers a form of collective action that inevitably rearranges villagers' relations. The pragmatic ideas of "issue" and "public" allow us to follow both the trajectory of landscape issues and the so-called opponents' collective attempt at constructing these issues as a shared problem. It also allows us to trace landscape issues without detaching them from local politics and its strategic delineation of the shifting public / private border, or from wind power policy and its associated state landscape, both of which offer a definition and practice of the General Interest (big "G", big "I"). Thus our analysis expands the strand of analytical works addressing landscape as a project and social assemblage (Briffaud 1995; Dewarrat et al., 2003; Nadaï 2007b; Nadaï and Labussière, 2010; Labussière and Nadaï, 2014).

Our analysis aims at relating the rise of conflict, and its relation to landscape, with the way in which public policy prioritizes a certain definition of public interests and human-landscape relations. French wind power policy is as much a landscape policy as it is an energy policy. It seizes upon the promotion of renewable energy as a means of addressing global warming and in so doing gives rise to new landscapes. It even seeks the emergence of new energy landscapes as a way of easing the development of wind power (Nadaï, 2011). Landscape issues arise from a tension between this intensive appropriation of a territorial dimension and a legally unqualified resource (wind).

Legal doctrines leave ownership patterns for the wind unspecified; they do not converge in endowing (or not endowing) intangible and unappropriated things such as wind with the status of res communis (Le Baut-Ferrarese and Michallet, 2012). Excluded from the cohort of goods, the resource of wind is commonly defined by its mere physicality, as a renewable flow. In France, this legal void is compounded by a policy framework that fosters private 
developers' initiative as the main vector for developing wind power. The ensuing privatization of wind power development hardly acknowledges its impact on the individual or collective organizations that underlie the sharing of local resources, including landscape. This situation is further complicated further by the fact that the state landscape, which supports wind power policy approaches to landscape issues falls short of acknowledging and addressing other forms of landscape commons. The state landscape is challenged even on its own terms and terrain - that of the multiple and extended visual relations among protected landscapes and proliferating wind turbines, which grow increasingly difficult to regulate (Nadaï and Labussière, 2011). Landscape issues thus meet either with inadequate forms of regulation (centralized tradition of landscape protection) or with none at all (uncharted legal status of the wind). This almost inevitably results in challenging and politicizing existing landscape practices or collective organizations at the local level. Such politicization may follow various paths. It may challenge the ways in which projects are developed, their underlying institutions (including wind power policy) and the way in which the private and the public spheres are articulated at the local level.

In our analysis, we follow the development of a wind power project and that of the network of actors who, from 2006 to 2009, came to challenge it and oppose wind power development on a broader scale: wind power project in the plateau south Gâtinais (Seine-etMarne). The analysis is based on archives and documents about the project process and recent village politics, and on thirty-four semi-structured interviews with governmental field services, associations (NGOs), individuals opposed to the project, and local councilors on the pro or con side of the issue. Field work was undertaken in 4 sessions (February 2008 October 2008 - March 2009 - April 2009). Most interviews were conducted at interviewees' homes or offices, but the material also includes in situ interviews with farmers in order to enter into their attachment to their living or working space (notably in the "plain"). Finally, we asked some interviewees to draw maps of their area of vigilance against wind power development and to discuss these areas according to their spatial or landscape practices. This allowed us to explore the collective organization of the (only partly formal) vigilance against wind power development in the plateau south Gâtinais.

\section{THE DIFFICULT BECOMING-PUBLIC OF A WIND POWER PROJECT}

\subsection{Pressure on the state landscape, a project Without a public}

In late 2003, two farmers from Ventville, a small village located in the south of Seine-etMarne (Parisian Basin), contacted a company developing industrial wind power projects. For the Seine-et-Marne administration, this project was a "première" 6 . As a way of enticing spatial planning, the administration required the developers active in the area to pool together and envision a unique wind power project comprising three communes: Ventville, Soville and Gatenville?

As elsewhere in France, wind power development challenged State landscape protection. The Seine-et-Marne Administration for Architecture and Landscape (SDAP in French) testified: "150 meters high turbines are out of scale compared with everything else we have in the département ${ }^{8} . "$ Taking up the challenge, the administration launched a new process.

\footnotetext{
${ }^{6}$ Authors' Interview,22 February 2008.

Nicknames.

${ }^{8}$ Authors' Interview, 21 October 2008.
} 
In April 2006, a white sounding-balloon was raised to the height of the future wind turbines in order to visualize materially their future presence in situ.

The regional and départemental services (environment, landscape, infrastructures and industry) crisscrossed the territory for one whole day in order to gauge and track the covisibilities of the future project sites highlighted by the sounding balloon (featuring the height of the future project), elements of the natural and cultural heritage, and houses. This experiment allowed the parties to consider project adjustments. It gave the administration a renewed capacity to view, have a say in and a control over the project in a context where usual landscape governance had been challenged. The process was not, however, brought to the attention of local residents.

As this experiment showed, wind power challenged the practice of the state landscape. First, it posed the cognitive challenge of gauging and visualizing in the field the future presence of the wind turbines (Nadaï and Labussière, 2015). It also put the underlying and historically constituted principles and hierarchies of values behind the state landscape to the test. Hitherto, the state landscape had implemented its values in a positive manner, selecting the most valued landscapes elements and barring developments which could impact on them negatively. But wind power, a spatially and visually colonizing infrastructure, instigated a different story. Its development ended up summoning landscape protection to a trial of explicitness. Barring a project is not the same as stopping wind power developers from searching for new sites until they find less valued landscapes to develop their projects. The pressure on wind power development thus revealed the ultimate expression and hierarchies of the state landscape. Implicitness was no longer sustainable. Valuing and protecting certain landscapes results in disqualifying others, since valuation steers project developments to the other, less valued landscape resources. The sounding balloon experiment testified to the state landscape's attempt to take up the new challenges and reorganize itself. Yet, whether out of rigidity or reluctance to be confronted with a politicization of their values when they were supposed to be objectively defending the landscape, administrative field services kept the public at a distance, even when responding to challenges (for example, the sounding balloon experiment).

Locally, the wind power project had an ambiguous status. The initiators of the project were two farmers. They owned enough land to site the wind turbines and contacted a private company, while excluding territorial authorities (for example, municipality, community of communes, local administration) from the loop. Since one of the project leaders was the mayor of Ventville, the initiative was bound to interfere with the local politics. As mayor, he was obligated to inform the villagers of any industrial project, and the neighboring municipalities of any wind power project in progress, that could have a visual impact on the landscape. In the early years of the project, these ambiguities remained unresolved.

\subsection{Private households in need of information - NOt Yet a "Public"}

The first inhabitants of Ventville to hear about the project were Mrs. and Mr. A. Their house was near the future wind turbines. They were thus privately concerned about the project. At that time, they held no firm position on wind power. Wanting to know more about it, they decided to go for a day long excursion to Janville, in the nearby Eure-et-Loir, and picnic at the foot of wind turbines: "We wanted to see how it felt to live there... it was supernatural! It was like being in another world." Back home, they surfed the internet, gathering 
information about wind energy and its effects and forging contacts with oppositional associations (Aude, Lévézou, "Vent de Colère"). They went to the town hall and met with the mayor. The wind power project grew more tangible. Mrs. and Mr. A. gradually became more and more vigilant. They attended all the municipal councils, beginning to give their private experience a public dimension. Their aim was to open up spaces for debate and negotiation about the wind power project.

In June 2006, a public information meeting was organized by the developer in the hamlet nearest the future wind farm. In late 2006, the mayor organized an informal meeting between the wind developer and Mrs. and Mr. A. The developer informed them that a wind power development zone proposal $\left(\mathrm{WPDZ}^{9}\right)$ had been filed by the city council with the prefecture in November. "At that point, we realized the project was fairly advanced ${ }^{10}$." Although they are rarely implemented in a participative way, WPDZ are a unique opportunity within the ongoing administrative procedures to devise locally shared orientations for wind power development (Nadaï and Labussière, 2009). Mrs. and Mr. A. asked the mayor to organize a public debate about the wind power project. "The process was already under way; he didn't want to ${ }^{11}$."

In January 2007, the developer filed a construction permit with the prefecture. Municipalities do not have the legal competence to grant or deny such permits, so that this decisive step can contribute to opening spaces for local debate.

Mrs. and Mr. A. gathered documentation about wind power and organized a consultation at their house. They invited anyone interested to attend the meeting, discuss the issue and possibly sign a petition. While the term "landscape" was not explicitly mentioned in the petition, the evocation of the "risk of disfiguring our environment"12 clearly referred to the local landscape, which the petition thus endowed with a collective status. Albeit initiated in the space of a private home, the process had a clear political reach: it aimed at organizing a collective and making a collective demand for a referendum on the project. The petition gathered 70 signatories, amounting to about one-fifth of the villagers (354 inhabitants in Ventville). "Initially, wind power was just a topic for discussion. By signing the petition, it was turned into a commitment," said one of the signatories.

In mid-March 2007, the petition was sent to the mayor of Ventville, to the prefecture of Seine-et-Marne and to some elected officials (deputy, départmental councilor). This new attempt to endow the issue with a public dimension and to spur debate at the local level remained unanswered. But the mayor was stunned. The list of petitioners included "some people [he] knew very well ${ }^{13}$." By leaving the mayor out of the process and then confronting him with the signed petition, they drew a line, identifying him not as a man they knew personally but as their formally elected representative. Thus the new wind power collective displaced the usual Ventville social order.

\footnotetext{
${ }^{9}$ The WPDZ is a national planning device, adopted in France in 2005. Local authorities, usually a group of communes, are encouraged to devise a local zoning for the development of wind power and to submit it for the approval of the local state representative - the departmental prefect. Only wind farms sited in the local WPDZ can then be granted the benefit of feed-in tariff. At the time of the Ventville project, WPDZ was a recently implemented policy framework (2007): developers often tried to streamline the devising of the zones by copy-pasting project impact studies. In the case of Ventville, the absence of formal intercommunality at the local level spurred the developer to take charge of devising the WPDZ. 10

Authors' Interview with Mr. and Ms. A., 19 March 2009.

${ }^{11}$ Authors' Interview with Mr. and Ms. A., 19 March 2009.

${ }^{12}$ Literally, "de défigurer notre environnement".

${ }^{13}$ Authors' interview with Mayor of Ventville, 24 October 200
} 


\subsection{THE PRIVATE / PUblic ARTICULATION, CHALLENGING THE RELATIONAL (COMMON) GROUND}

"Locally, it is not politicized at all. It's familial [...]; the same in the surrounding villages. It's an 'agricultural policy' ${ }^{14}$." The expression "agricultural policy" points to the power of old families that own and manage large farms over village life, local politics and governance. Elective functions, such as mayor and councilor, boil down almost to a generational inheritance.

Beyond the city council, these familial and socio-occupational schemes structure associative life in Ventville. "N.D. is the mayor of Ventville; his father is the president of the hunting association; his mother is the president of the Seniors Club; his wife chairs the celebration committee. It's like that in small villages. It's their [the farmers] world ${ }^{15}$." Through this collusion between the agricultural community and positions of local responsibility, municipal life derives vitality from coherent and influential family circles.

While promoting the reproduction of local elites, this articulation has also long evinced virtues. It is an open game ensuring the animation and good reputation of the village. Newcomers are welcomed. They are helped. They agree to take part in the collective organization of the local life, as did Mrs. and Mr. A. Reciprocity is made possible between a relatively circumscribed political management and a more open social life fostering individual participation.

Wind power was thus introduced into a social fabric in which political relationships were interwoven with proximity, in which the mayor, for instance, has the position of a leader. It destabilizes this cooperative game and its regulating roles, which can be regarded as a genuine relational common ground.

The petition opened a new political space. The collective dimension of the project, until then restricted to private encounters (the informal meeting of Mrs. and Mr. A., the developer and the mayor; consultation at Mrs. and Mr. A.'s house), and the demand for a referendum, gained a new presence. The public dimension of the project overflowed the usual procedures (state landscape governance, WPDZ process) and gained a political dimension (engaging the mayor as both an elected representative and a project leader).

The petition was addressed to the mayor as an elected representative, a position which he had attempted to use to his personal advantage. " [...] we are elected, we have projects. If they do not appeal to you, there are other elections to kick us out. In my view, that's local democracy ${ }^{16}$." While the mayor's rhetoric presupposed that the project enjoyed a shared / public interest, in fact it was never included in his electoral program.

This trapped him. By clinging to his mandate in order to assert his legitimacy to decide on the project, the mayor cut himself off from his usual political relationship: a relationship that not only grounded his legitimacy but also related him to issues in a qualitative way that made them available to negotiation.

As far as Mrs. and Mr. A. were concerned, the project was negotiable: "We were never against wind power; we were against this project ${ }^{17}$." Their agreement was conditional upon

\footnotetext{
${ }^{14}$ Authors' Interview with Mr. and Ms. A., 19 March 2009.

${ }^{15}$ Authors' interview with Mr. and Ms. A., 19 March 2009.

${ }^{16}$ Authors' interview with the mayor of Ventville, 24 October 2008

${ }^{17}$ Authors' interview with Mr. and Ms. A., 19 March 2009.
} 
changes in the siting of the project " [...] the second [turbine], for example, was too close [to our house] ${ }^{18 " ~ H a d ~ a ~ r e f e r e n d u m ~ t a k e n ~ p l a c e ~ a n d ~ l e d ~ t o ~ a ~ p l e b i s c i t e, ~ t h e y ~ w o u l d ~ h a v e ~}$ accepted the siting of the turbines. "We could have put the house up for sale; then it would have become our problem. [As things were] we weren't part of the process at all ${ }^{19}$."

The mayor's defense fell short of dispelling the ambiguity of his attachment to the project: modalities for endowing this project, and its associated landscape, with a shared and collective dimension are yet to be defined.

\subsection{THE "PLAIN", TENSIONS OVER AN AGRICULTURAL COMMONS}

The "plain" is a case in point. It is an agricultural area (several hundred hectares) located in the commune of Ventville. The plain has recently been consolidated without conflicts. As Mr. L., President of the Ventville Land Consolidation Association, has stated, the plain owes its agricultural potential to successive land consolidations, which allowed the farmers' collective to counter intergenerational land fragmentation and maintain the spatial continuity of their individual farming property. The very configuration of the plain (size, regular topography, homogeneous quality) facilitates this otherwise conflictual exercise of assessment/categorization/exchange of plots of lands: "This is precisely where a wind power project becomes problematic." As Mr. L. pointed out, the presence of a wind farm may complicate the next consolidation. It may raise issues such as the recipient of rents from wind power when plots of lands are exchanged, how underground cables are dealt with when assessing the plots, who is liable for dismantling of the wind farm if the developer goes bankrupt.

The development of the wind farm thus introduced heterogeneities into the plain. It also established new ways of relating to the land (e.g. construction site of the turbines, material presence of cables, rents) that do not take the collective / intergenerational management of the plain by the farmers into account. Rental contracts were devised and signed in secret between the developers and individual farmers. The land consolidation association was not kept in the loop. Farmers contracted individually for a given acreage on their land, corresponding to the siting of a given number of turbines, without knowing where these turbines would be located. Not only did wind power introduce a new type of privatization into the plain, where collective responsibility and management had formerly prevailed; it was also an intrusion into this relational network: "Usually the mayor doesn't decide what happens in the plain; the idea is that this is the job of the President of the Association." By supporting a private, developer-led wind power project, the municipality encroached upon a self-governing agricultural community and its space.

\subsection{Emerging as a public, the SOUth Gâtinais Plateau as a common and political space}

The petition from the Ventville collective was not really followed-up. But it allowed this collective to make contact with different associations of wind power opponents in the south (APPGS, ADER) and the north of the department ("Wind of Truth" [Vent de verité]). The Association for the Protection of the South Gâtinais Plateau (APPGS), created in January 2007 by the inhabitants of a neighboring village, was rapidly becoming the coordinating entity for these different groups.

\footnotetext{
${ }^{18}$ Authors' interview with Mr. and Ms. A., 19 March 2009.

${ }^{19}$ Authors' interview with Mr. and Ms. A., 19 March 2009
} 
The APPGS was radically opposed to wind power and justified its position by a critique of French wind policy: "Industrial wind power is a financial windfall for unscrupulous people. 20." The president of the APPGS emphasized this point: "I'Il excuse even the mayors. The state has laid the foundation through 'laissez-faire'. In small villages, mayors don't have much to manage. A wind power project exceeds their capacities and competence. ${ }^{21}$." Thus the APPGS straightforwardly positioned itself in the political field and called upon mayors to take their stand on wind power.

In early 2007, the Association organized two to three public meetings a week in villages. This covered the southern Seine-et-Marne. The APPGS persuaded many communes that were already talking to wind power developers to take a stand against wind power. It turned wind power into a problem on a much broader scale: the entire southern part of the department.

The production of this scale of vigilance was an innovative process testifying to a search for a space of reference in which the territorial and landscape changes initiated by wind power could become collectively negotiable. The southern Gâtinais emerged as this new political space. It APPGS existed of course before wind power raised these various issues, but the emergence of a strategic monitoring, collectively undertaken by the members of this network, and associated with designated areas of responsibility and translated into practices of individual vigilance, may be regarded as a form of collective organization.

Figure 2. [Please insert here] Ms. A's area of vigilance against wind power (circles) "This is all my zone [refusing wind power]. So here it's regional. I've covered it all ${ }^{22}$."

Figure 3. [Please insert here] Ms. N's area of vigilance against wind power: "As soon as wind power was on the agenda of a local council, we got going. We really patrolled. Then I became an opponent. We thought it necessary to stop all the surrounding projects so that our project would have no chance of getting through ${ }^{23}$."

Such a collective organization marks a change in this shared resource from the status of a plateau to that of a commons. Admittedly, an emergent commons, perhaps a temporary commons, yet a commons that allows for challenging French wind power policy, its emphasis on energy production and its lack of transparency in local arbitration.

For the mayor of Ventville, this period was "hard to live through ${ }^{24}$." While oppositional meetings multiplied, he tried to organize a public meeting with the support of state officials. However, in the context of upcoming national elections (the presidential one in April and May 2007, the parliamentary in June 2007), the administration adopted a distance to issues such as wind energy, which easily tend to become politically controversial.

\subsection{BECOMING PUBLIC, RADICALIZATION AND DISLOCATION OF VILLAGE LIFE}

While the APPGS quite effectively fostered the local opposition to wind power, the demand for a local referendum in Ventville, included in the petition, was not followed through on. If radicalization is an easy way to publicize an issue, it is also a trap. Once positions were fixed

\footnotetext{
${ }^{20}$ Authors' interview with the APPGS, 22 October 2008.

${ }^{21}$ Authors' interview with the APPGS, 22 October 2008.

${ }^{22}$ Authors' interview with Mr. and Ms. A., 19 March 2009.

${ }^{23}$ Authors' interview with Mr. and Ms. A., 19 March 2009.

${ }^{24}$ Authors' interview with the mayor of Ventville, 24 October 2008
} 
and perceived as "opposition", it became more difficult to go back to the original intention of negotiating the project.

Our interviews show that many villagers were not initially opponents of wind power. On the contrary, they seem to have developed into opponents as a result of being ignored by institutions and policy-makers.

Wind power threw Ventville into chaos; interpersonal conflicts raged and social life was dislocated. Looking back brings a taste of bitterness: "Our village used to be famous for its very good atmosphere ${ }^{25}$." Village life literally imploded. Our interviews show that there is a before and an after to wind power.

In the absence of a referendum, Mrs. and Mr. A. and a few other inhabitants publicly demonstrated their opposition. "We put up posters with 'No to the wind turbines', stuff like that. But we asked the owners of the houses before putting up the posters. The mayor was warned. We did things properly ${ }^{26} . "$

Figure 4. [Please insert here] Protest posters against the wind power project at the entrance to Ventville

The animosity surrounding the project in 2007, right after the failure of the petition and the validation of the WPDZ by the Prefecture (May 16), triggered excesses. On the morning of June 2007, residents discovered protest graffiti in the heart of the village. Mrs. and Mr. A. were summoned to police headquarters. Bottles and garbage were thrown at the mayor's and at Mrs. and Mr. A.'s houses. The troublemakers remained unidentified.

The confusion progressively led to a dislocation of social life and a disengagement of individuals from the collective activities: "In Ventville, there's no longer any public life, it's all ruined $^{27 "}$ "; "Before there was a political right and a political left, as everywhere. Now wind power has mixed up everything. It caused breaks between good friends, or brought people together who had never spoken to each other before ${ }^{28}$."

\subsection{PROCEDURES FALLING SHORT OF ENDOWING WIND POWER WITH A PUBLIC DIMENSION}

In spite of the major tensions triggered by the project in 2007, the mayor did not put it up for debate. In March 2008, with the upcoming municipal elections, the project resurfaced and became a dividing line. For the first time in the history of the small village, an opposition list campaigned. Initiated by Mrs. and Mr. A., it advocated an alternative to the traditional "agricultural policy" and the cancellation of the wind power project.

As far as wind power was concerned, the municipal election brought as many clarifications as it raised ambiguities. For the mayor, "our opponents have always demanded a referendum [on wind power]. I told them: you'll soon have it [with the elections] ${ }^{29}$." The city council remained almost unchanged while the opposition list was roundly defeated. But since the election covered much broader issues than wind power, the voting was insufficient to give the project a genuine public dimension.

\footnotetext{
${ }^{25}$ Authors' interview Mr. and Ms. A., 19 March 2009

${ }^{26}$ Authors' interview Mr. and Ms. A., 19 March 2009

${ }^{27}$ Authors' interview with Mr. and Ms. C., 18 March 2009

${ }^{28}$ Authors' interview with Mr. and Ms. N., 21 April 2009

${ }^{29}$ Authors' interview with the mayor of Ventville, 24 October 2008
} 
On 8 July 2008, the building permit for the Ventville-Soville project received a favorable notification from the départmental Commission for Nature, Landscapes and Sites (CDNPS). Financial, technical and landscape issues were discussed, but local disputes not were even mentioned. Then, on 12 February 2008, the part of the project located in the Loiret département was granted a building permit, making it harder for the Seine-et-Marne administration to advise against the remaining part of the project (eight turbines).

The public inquiry, organized by the local administration and the administrative court, was held in the autumn of that same year. Opponents went there together. In spite of there being "about a hundred reasoned opposing opinions and only ten favorable ones, four of which came from the Soville municipal councilors ${ }^{30 "}$, the commissioner delivered a favorable judgement. Disappointment was total: "He [the commissioner] concocted amalgam, stating that given the results of the municipal elections and the strong re-election of the mayor, anti-wind power opinion didn't represent the village ... a public inquiry with a report like that, no, it doesn't deserve the name ${ }^{31}$." It should be noted that the same critics acknowledged the quality of a public inquiry in a neighboring village, in which the commissioner delivered a favorable opinion on another project. On 11 February 2009, the prefecture granted permission for the remaining (eight) wind turbines to be built in Ventville-Soville. In spite of the APPGS court appeal, in May 2013 a construction permit was definitively granted for seven of the eight turbines; one was cancelled for overflight reasons.

Eventually, neither the municipal elections nor the public inquiry nor the appeal to the administrative court succeeded in endowing the wind power project with a negotiated and shared dimension. Instead, the local elections resulted in a biased framing of the issue. It staged the social as "problematic", but left the local ramifications/embedding of wind power technology, the source of so many local disruptions, uncharted and undiscussed.

\section{A WIND UNDER COMMON LAW, WITHOUT ITS COMMONS}

The previous case study points to ways in which a wind project can trigger the disorganization of different types of commons: a relational commons made up of the intimate interweaving of public and private interests in the village of Ventville, and a landscape commons resulting from the coexistence of informal (walking, hunting) or institutionalized uses (agriculture, land consolidation) in the "plain".

Thus we can easily see that a certain type of wind power, capitalist and privately developed, while not exhausting the wind resource and being able to claim renewability, may nevertheless exhaust certain common resources that underlie (village) social organizations.

The legal void that qualifies wind as a thing which does not belong to anybody and whose use is open to anybody does not stop or regulate the competition between wind power and other uses of resources that are needed to harness the wind. Landscape seems far from and unconnected to the use of free and renewable wind. But it is part of the resources on which wind power developers lean, through an array of uses articulated through the organization of space, social life, land uses and land productivity in order to access the wind.

\footnotetext{
${ }^{30}$ Authors' interview with Mr. and Ms. A., 19 March 2009.

${ }^{31}$ Authors' interview with Mr. and Ms. A., 19 March 2009.
} 
To understand the nature of the competition over these resources, we must remember that, in the EU, the emergence of wind power policy began with a heated debate on the merits of different policy instruments (i.e. price, premium, quota certificate). Wind power policy has thus somehow emerged in midstream, leaving behind, unchallenged, the status of the resource and its modes of appropriation. This history has to some extent contributed to making the distribution of wind power benefits more problematic, for the difficulties must be solved in and around individual projects, in a context where actors' interests are already formed (some have investments, others expectations).

In France, this picture is further complicated by the predominance of private and individual initiatives behind wind power development. Within the current market tropism of public policy stance, this development is supposed to be geared to private profit and freed from social/institutional barriers. Private developers are not supposed to undertake the timeconsuming and expensive work of acknowledging (the varied) collective resource organizations and sharing. In such a context, the capacity of the institutions to endow wind power projects with a collective dimension is fragile. French wind power policy is associated with a stated public dimension (national quantitative targets, feed-in tariff). Yet it relegates to the local level, without genuinely supporting it, the work of collective coordination that is necessary to give a wind power project a shared, if not public, interest at this level. In our study, neither the administration nor the developer attempted to open a space for discussion about the actual resources engaged in the project, the organization or practices underlying the current sharing of these resources, and alternative ways of proceeding in this context. Elected officials were left alone to face their constituents and shoulder the tensions triggered by private profit-driven wind power.

Elinor Ostrom (2013) has emphasized the abstractness and the fallacy of the public/private divide when it comes to understanding the regulation of common pool resources. Our analysis confirms to some degree this view by pointing to both the foregrounding of a public and a private dimension in French wind power policy (quantitative targets and tariffs vs private initiative) and the dramatic lack of acknowledgement of the collective processes underlying these interwoven dimensions. The private and the public dimensions of French wind power policy were addressed separately; they were kept apart as disjoint sets. On the one hand, private developers seized the resources without acknowledging, if not indeed by positively undoing, the collective organizations underlying them. On the other hand, the public administration, for the sake of neutrality, focused on "due" procedures and disregarded the tensions stemming from diverging private interests. Nowhere were the tensions addressed that ensue from the engagement of shared resources in the development of wind power. The result was that landscape was either not taken into account at all (by turning wind into an independent and isolated resource, reduced to its physical/kinetic flow) or else inadequately approached (by protecting the "state landscape" without considering the consequences of this protection). It was unlikely that landscape commons, which weave together public and private interests, would be sustained.

In other words, the type of wind power analyzed in this case study is a sort of fault line. In its way it splits commons apart, renders the public or private interests incommensurable, and results in what can be called an "end of the commons". The social life in Ventville disintegrated because the farming families that animated it were stultified by wind power. They owed their influence to interweaving between family logics (private) and municipal 
responsibilities (public). Wind power equated the former with capitalist profit, and exceeded the latter because its scale and attachments went beyond ordinary management. Similarly, with regard to the management of the plain and the organization of agricultural life, wind power thwarted the working of a commons. Wind power developers introduced a logic of appropriation (siting private infrastructure, negotiating individual rents, uncertain transmission and liability) that diverted the farmers from collective organization in the plain and from the underlying solidarity that made smooth periodic land re-organization possible(impact on land consolidation) and produced negative externalities (underground wiring).

In our analysis, we have often pointed to actors' difficulty in re-opening a space for debating the status of the resources in order to prevent the end of a commons. A way out of this difficulty would be to approach the wind resource, at first so fluid and aterritorial, through the analysis of specific landscape configurations and their bundles of uses. The emergence of the South Gâtinais plateau anti-wind power collective should be regarded as an attempt both to structure a new landscape commons and to establish a collective regulation of access to the resources such as was hampered at the scale of wind power projects.

\section{CONCLUSION}

Our case study suggests that local opposition to wind power is symptomatic of the shortcomings of an institutional environment in acknowledging the shared resources which are engaged in the development of wind power projects. Shared resources are a locus where the articulation of the public and private dimensions of wind power policy is at stake. Understanding the social tensions caused by wind power reveals the difficulty of wind power policy in articulating its public and private dimensions.

In France, wind power policy is posited as a matter of public interest. This dimension, however, remains to be co-constructed on a project by project basis, digging into the ways in which the shared resources engaged in the development of these projects, including landscape commons, convey collective organizations and public/private embedding. Local elected representatives and municipalities often find themselves faced with the challenge of managing the social and political processes required for re-embedding these interests in wind power projects in the absence of public mediation.

Our analysis highlights two key points. First, the status of wind as an energy resource has never been genuinely debated, either at the European or at the French level. Second, framing the wind through its sheer abundant and fluid physicality conveys neither the collective dimension nor the bundle of uses attached to the landscapes engaged in harnessing the wind. The resulting tensions remain imperfectly understood.

In our case study, the individual trajectories underpinned by these tensions bear witness to individuals seeking support in addressing a collective dimension and construct an oppositional posture in the face of failing policy or institutional arrangements. They are not opponents of wind power per se. Opposition is formed by the tension exerted by (French, privately developed) wind power on commons (relational, landscape). If these tensions induce the fragmentation of certain commons, they also trigger the emergence of new ones, aimed at challenging (French) and changing wind power policy. 
On this analysis, opposition and landscape issues in relation to wind power should not be assimilated to conservationism. They should rather be seen as demands to recognize the necessary collective underpinnings of wind power projects and, therefore, as a potential contribution to the emergence of new forms of energy citizenship.

\section{ACKNOWLEDGEMENTS}

This work was carried out with the financial support of the French National Research Agency (ANR, programme sociétés innovantes, convention 2011- SOIN-003-01, projet COLLENER), the French Ministry for the Environment (MEDDAD - Program PDD "Paysage et Développement Durable"), the "Conseil Français de l'Energie", the French Agency for the Environment and the Energy (ADEME) (Convention $0710 \mathrm{C}$ 0019), the Region Ile-de-France and the Centre National de la Recherche Scientifique (CNRS - Programme Interdisciplinaire pour l’Energie). 


\section{REFERENCES}

Aitken Mhairi, McDonald Seonaidh and Strachan Peter, 2008, "Locating 'power' in wind power planning processes: the (not so) influential role of local objectors", Journal of Environmental Planning and Management, Vol. 51, No. 6, November, 777-799

Bellivier Florence, Benhamou Françoise, Cornu Marie et Noiville Christine, 2015, " Collections muséales et collections biologiques : de la conservation à l'accès ? ", in "Le retour des communs » Coriat B. (dir.), pp 197-221, Les Liens qui Libèrent, Paris.

Bender B., 1998, Stonehenge: making space. Berg, Oxford, UK.

Bishop ID, Miller, 2007, Visual assessment of off-shore wind turbines: The influence of distance, contrast, movement and social variables, Renewable Energy, 32 (5) 814-831.

Bolinger Mark A. 2005, Making European-style community wind power development work in the US", Renewable and Sustainable Energy Reviews, (9) 556-575

Briffaud, S., 1995, « Découverte et représentation d'un paysage: Les Pyrénées du regard à I'image (XVIII-XIXe siècles) ", in A. Roger (dir.), La Théorie du paysage en France (1974-1994). Seyssel, Champ Vallon, coll. « Pays/Paysages », p. 224-259.

Callon Michel, Lascoumes Pierre et Barthe Yannick, 2001, Agir dans un monde incertain. Essai sur la démocratie technique. Paris: Seuil.

Coriat, B., 2013, "Le retour des communs ", Revue de la régulation, $\mathrm{n}^{\circ} 14$, automne.

Coriat, B., 2015, Le retour des communs : La crise de l'idéologie propriétaire. Coriat B. (dir.), Les Liens qui Libèrent, Paris, pp298.

Cowell R., 2010, Wind power, landscape and strategic, spatial planning-The construction of 'acceptable locations' in Wales, Land Use Policy, 27, pp 222-232

Dewarrat, J.-P., 2003, Quincerot, R., Weil, M., Woeffray, B., Paysages ordinaires: de la protection au projet. Mardaga, coll. " Architecture + recherches », Bruxelles.

Dewey John, 2003, Le public et ses problèmes, trad. et introd. J. Zask, Pau : Farrago / Léo Scheer.

Ellis, Geraint, Cowell, Richard, Warren, Charles, Strachan, Peter, Szarka, Joseph, Hadwin, Richard, Miner, Paul, Wolsink, Maarten and Nadaï, Alain, 2009, 'Wind Power: Is There A "Planning Problem"? Expanding Wind Power: A Problem of Planning, or of Perception? The Problems Of Planning-A Developer's PerspectiveWind Farms: More Respectful and Open Debate Needed, Not Less Planning: Problem "Carrier" or Problem "Source"? "Innovative" Wind Power Planning', Planning Theory \& Practice, 10: 4, 521 - 547

Gee K., 2010, Offshore wind power development as affected by seascape values on the German North Sea coast, Land Use Policy, 26(3), pp. 185-195.

Hirsch E., 1995, Landscape: between space and place. In: Hirsch E, O'Hanlon M (eds) The anthropology of landscape: perspectives on place and space, Oxford University Press, Oxford, pp 1-30 
Jolivet, E. \& Heiskanen, E., 2010, Blowing against the wind-An exploratory application of actor network theory to the analysis of local controversies and participation processes in wind energy, Energy Policy, 38, pp. 6746-6754.

Labussière, O. et Nadaï, A., 2014, « Unexpected wind power 'potentials': the art of planning with inherited socio-geographical configurations (France)", Scottish Geographical Journal, vol. 130, n³, p. 152-167.

Latour Bruno, 1991, We have never been modern. Cambridge: Havard University Press.

Le Baut-Ferrarese B. et Michallet, I. 2012, Traité de droit des énergies renouvelables, Paris, Éditions Le Moniteur, 2e édition.

Marres N., 2012, Material Participation. Technology, the Environment and Everyday Publics. London: Palgrave Macmilan.

Marres, N., 2007, "The Issues Deserve More Credit: Pragmatist Contributions to the Study of Public Involvement in Controversy ", Social Studies of Science, $n^{\circ} 37$.

Meyer, N.I., 2007, Learning from wind energy policy in the EU: lessons from Denmark, Sweden and Spain, European Environment, 17(5), pp. 347-362.

Mitchell WJT, 1994, Landscape and power. University of Chicago Press, Chicago

Möller, B., 2010, Spatial analyses of emerging and fading wind energy landscapes in Denmark, Land Use Policy, 26(3), pp. 233-241.

Nadaï A. \& Labussière O., 2015, "Wind power and the emergence of the Beauce landscape (Eure-et-Loir, France)", Landscape Research, vol 40 (1), p 76-98.

Nadaï A., Labussière O., 2014, "Communs paysagers et devenirs éoliens opposés : Le cas de la Seine-et-Marne (France)", Projet de Paysage, 29 septembre [revue en ligne].

Nadaï, A. et Labussière, O., 2009, "Wind power planning in France (Aveyron): from State regulation to local experimentation ", Land Use Policy, vol. 26, n 3, p. 744-754.

Nadaï, A. et Labussière, O., 2010, "Birds, turbines and the making of wind power landscape in South France (Aude) », Landscape Research, vol. 35, n², p. 209-233.

Nadaï, A. et Labussière, O., 2011, "Eoliennes: États d'un paysage d'État ", La Pierre d'Angle. Revue des Architectes des Bâtiments de France, Paris, $n^{\circ}$ 56-57, p. 28-31.

Nadaï, A., 2007a, " "Planning", "siting" and the local acceptance of wind power: Some lessons from the French case ", Energy Policy, vol. 35, n 5, p. 2715-2 726.

Nadaï, A., 2007b, "Degré zéro: Portée et limites de la théorie de l'artialisation dans la perspective d'une politique du paysage ", Cahiers de géographie du Québec, vol.51, n¹44.

Nadaï, A., 2011, "Politique de l'énergie et paysages éoliens " dans Oueslati, W. (dir.), Analyses économiques du paysage. Versailles, Éditions Quae, p. 247-263.

Nadaï, A., 2012, 'Planning with the missing masses: innovative wind power planning in France' in: Szarka J., Cowell R., Ellis G., Strachan P. and Warren C. (eds.) Learning from Wind 
Power: Governance, Societal and Policy Perspectives on Sustainable Energy. Palgrave, Mac Millan, pp280.

Nielsen, F.B., 2002, A formula for success in Denmark, in Pasqualetti MJ, Gipe RW, Righter RW. (eds) Wind Power in View: Energy Landscapes in a Crowded World. Academic, London, pp. 115-132.

Ostrom, E. et Basurto, X., 2013, " Façonner des outils d'analyse pour étudier le changement institutionnel ", Revue de la régulation, $\mathrm{n}^{\circ} 14$, automne.

Ostrom, E., 2013 [1990], Gouvernance des biens communs. Pour une nouvelle approche des ressources naturelles. Bruxelles, De Boeck.

Pearson Thomas W., 2016, Frac Sand Mining and the Disruption of Place, Landscape, and Community in Wisconsin, Human Organization, Vol. 75, No. 1

Pestre Dominique, 2013, A contre-science. Politiques et savoirs des societies contemporaines. Paris: Seuil.

Toke, D., Breukers, S. \& Wolsink, M., (2008,) Wind power deployment outcomes: How can we account for the differences?, Renewable and Sustainable Energy Reviews, 12(4), pp. 1129-1147.

Willow Anna J., 2014, The new politics of environmental degradation: un/expected landscapes of disempowerment and vulnerability, Journal of Political Ecology, Vol. 21.

Willow Anna J., Zak Rebecca, Vilaplana Danielle, Sheeley David, 2014, "The contested landscape of unconventional energy development: a report from Ohio's shale gas country", J Environ Stud Sci, 4:56-64

Willow Anna, Wylie Sarah, 2014, Politics, ecology, and the new anthropology of energy: exploring the emerging frontiers of hydraulic fracking, Journal of Political Ecology Vol. 21.

Wolsink, Maarten 2009 Planning: Problem "Carrier" or Problem "Source"?, Planning Theory \& Practice, 10: 4, $539-543$

Zografos, C. \& Martínez-Alier, J., 2009, The politics of landscape value: a case study of wind farm conflict in rural Catalonia, Environment and Planning A, 41(7), pp. $1726-1744$. 
FIGURES

\begin{tabular}{|c|c|c|c|c|c|c|c|c|c|c|c|c|c|c|}
\hline $\begin{array}{c}\text { Type of } \\
\text { landscape } \\
\text { representation }\end{array}$ & $\begin{array}{c}\text { WP } \\
\text { devpt } \\
\text { zone or } \\
\text { scheme }\end{array}$ & // $\begin{array}{c}\text { Project } \\
\text { design }\end{array}$ & $>$ & $\begin{array}{l}\text { Impact } \\
\text { studies }\end{array}$ & $>$ & $\begin{array}{l}\text { Administ. } \\
\text { Notification }\end{array}$ & $>$ & $\begin{array}{l}\text { Public } \\
\text { inquiry }\end{array}$ & $>$ & $\begin{array}{l}\text { Prefect } \\
\text { advice }\end{array}$ & $>$ & $\begin{array}{l}\text { Court } \\
\text { appeal }\end{array}$ & $>$ & $\begin{array}{c}\text { Final } \\
\text { decision }\end{array}$ \\
\hline Formal & ++ & ++ & & ++ & & ++ & & ++ & & ++ & & ++ & & ++ \\
\hline Informal & + & + & & - & & -- & & + & & + & & - & & -- \\
\hline $\begin{array}{l}\text { Ventville } \\
\text { project } \\
\text { chronology }\end{array}$ & 2007 & $\begin{array}{l}\text { Fall } \\
2003 \\
\text { June } \\
2006\end{array}$ & & $\begin{array}{c}\text { Spring } \\
2006\end{array}$ & & $\begin{array}{l}\text { Spring } \\
2008\end{array}$ & & $\begin{array}{l}\text { Fall. } \\
2008\end{array}$ & & $\begin{array}{l}\text { Winter } \\
2009\end{array}$ & & $\begin{array}{l}\text { Spring } \\
2009\end{array}$ & & $\begin{array}{l}\text { Spring } \\
2013\end{array}$ \\
\hline
\end{tabular}

++ important; +- variable ; -- not frequent

Figure 1. Table of acknowledgement of the landscape dimension in French administrative procedures for wind power and the chronology of the Ventville project

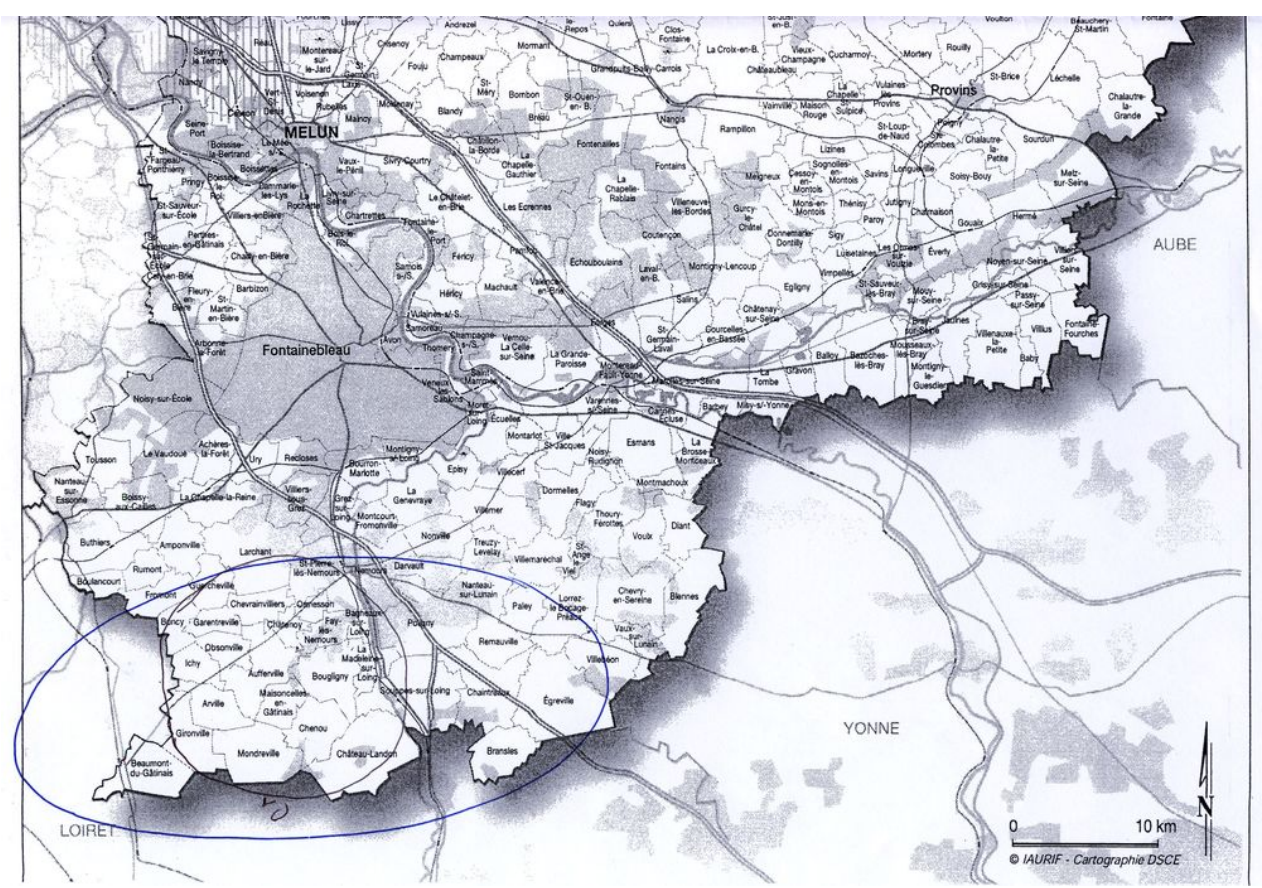

Figure 2. Ms. A. area of vigilance against wind power (circles) "This is all my zone [of refusal of wind power]. So here it's regional. I have covered all that ${ }^{32} . "$

\footnotetext{
${ }^{32}$ Authors' with interview with M. and Mme A., 19 March 2009.
} 


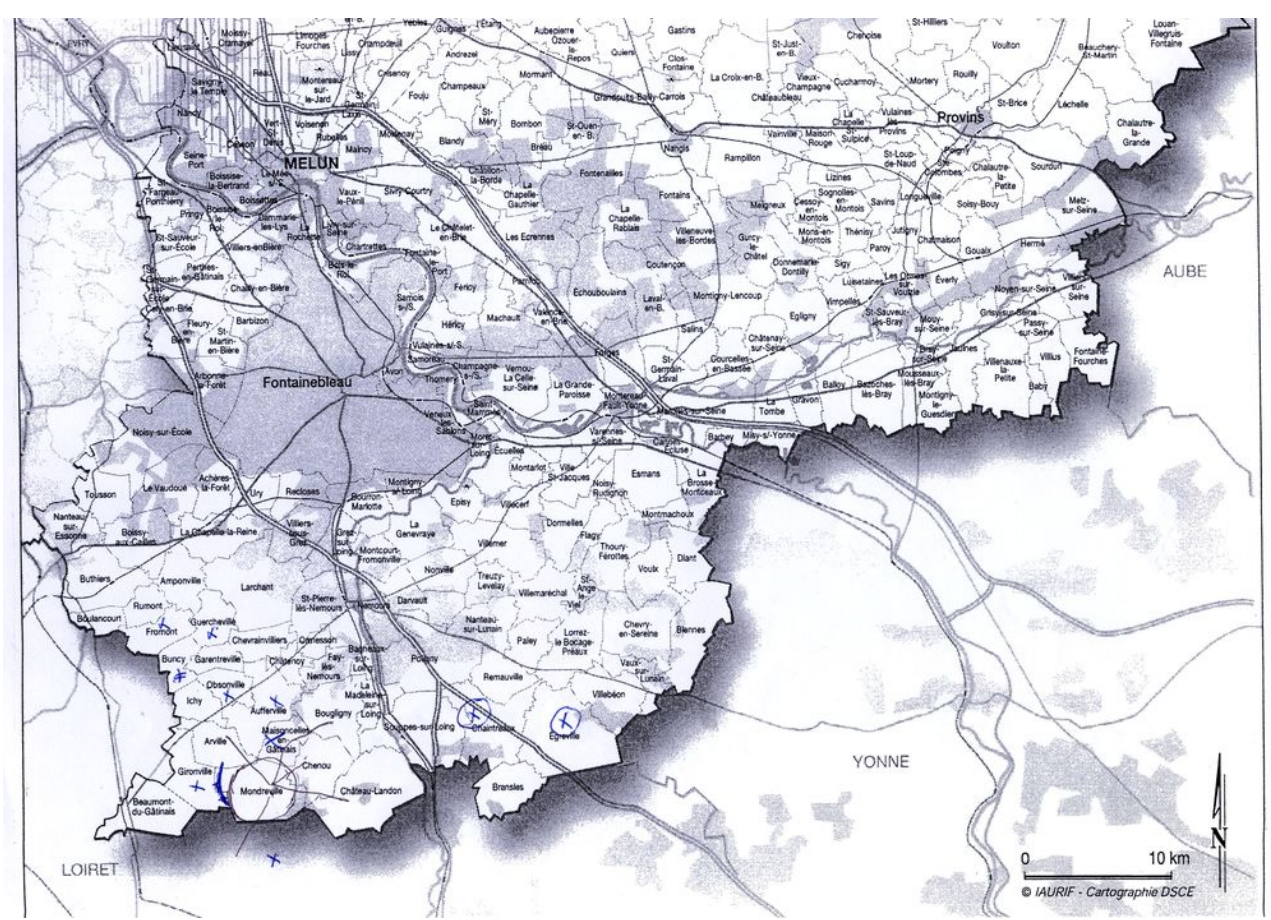

Figure 3. Ms. N's area of vigilance against wind power: "As soon as wind power was on the agenda of a local council, we went. We actually went on patrol. Then, really, I was an opponent. We thought it was necessary to stop all the surrounding projects for our project not to have any chance of getting through ${ }^{33}$."

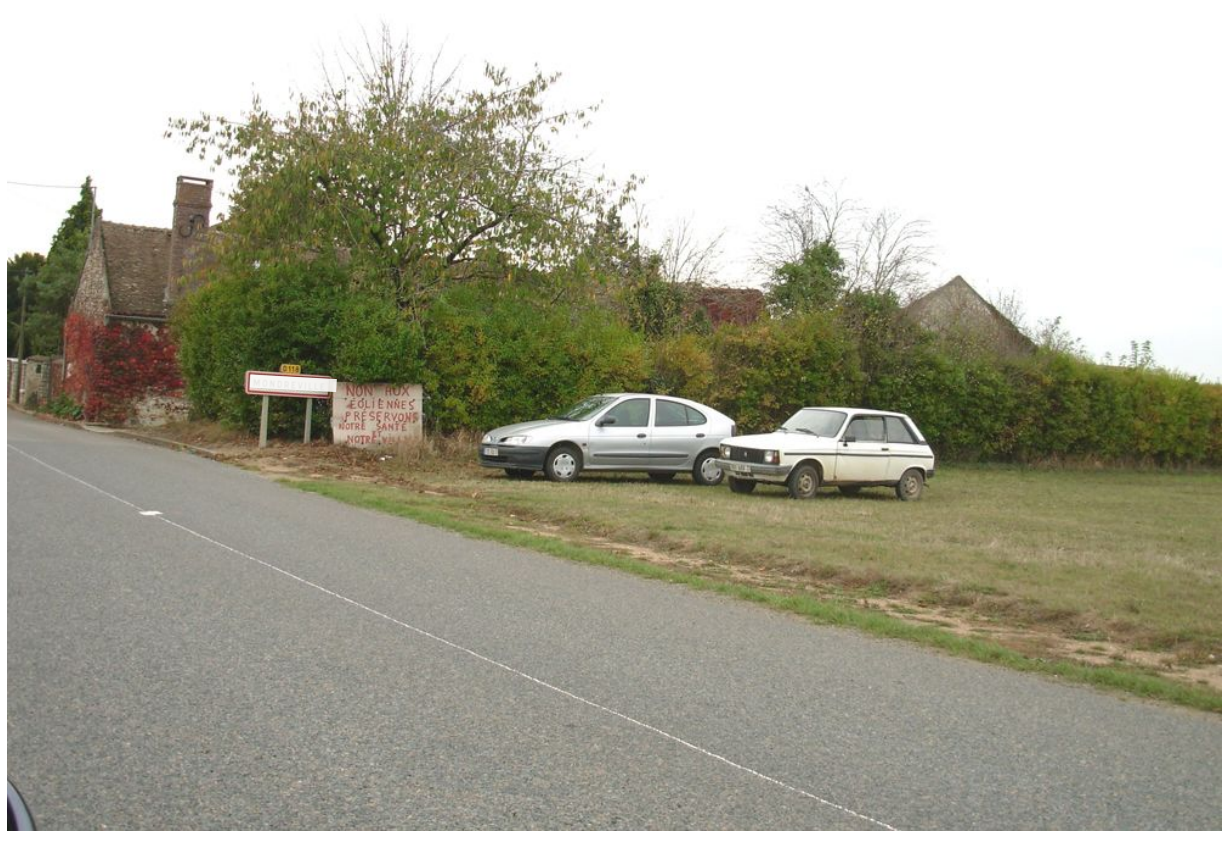

Figure 4. Protest poster against the wind power project at the entrance to Ventville

\footnotetext{
${ }^{33}$ Authors' interview with M. and Mme A., 21 April 2009.
} 